\title{
A participação da Rádio Nacional na difusão do futebol no Brasil nas décadas de 1930 e 1940
}

\author{
Daniel Damasceno Crepaldi \\ Orientador: Prof. Dr. Aldo Antonio de Azevedo \\ Curso: Mestrado em Sociologia \\ Data da defesa: 09.11.2009
}

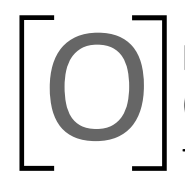

presente trabalho procura analisar a participação do Estado Novo (1930-1945) e da Rádio Nacional na difusão do futebol pelo território brasileiro. Investigou-se a possibilidade de utilização da rádio pelo poder público como veículo de propagação ideológica, tendo como vetor o futebol. Sabe-se que o esporte foi - e ainda é - usualmente utilizado por governos, ditadores ou não, para implementação ou reforço da noção de identidade nacional de um povo.

Foi feita uma análise sobre a forma como se deu a entrada e a difusão do futebol pelo Brasil, chegando-se à conclusão de que tal propagação não ocorreu por uma única porta, como o senso comum normalmente reproduz, mas sim, por várias vias espalhadas pelos diversos estados brasileiros, contando com a participação de diferentes indivíduos em espaços de tempo relativamente curtos. Da mesma forma, buscou-se retratar o rádio, como veículo de comunicação, desde sua chegada ao país, perpassando pelos decretos governamentais que regulamentaram a ação deste veículo, até a atuação especificamente da Rádio Nacional, nos meios cultural e esportivo, como órgão inicialmente privado, e posteriormente, encampado pelo Estado. A atuação do governo federal brasileiro durante a Era Vargas, desde a profissionalização do futebol à sua relação com os meios de comunicação, também constou entre os principais fatores da análise.

As bases do trabalho foram análises bibliográficas sobre os temas pesquisados (sem a intenção de se utilizar autores específicos) além de entrevistas com informantes-chaves, que foram de extrema importância para a sustentação das afirmações feitas ao longo desta dissertação. Ao final do trabalho, as hipóteses iniciais não foram confirmadas, na medida em que não se percebeu influência direta do Estado em seu principal veículo de comu- 
nicação - a Rádio Nacional - no tocante à utilização do futebol como fonte de exploração ideológica.

Palavras-chave: Futebol; Rádio Nacional; Era Vargas; ideologia. 